\title{
Dampak Infrastruktur Terhadap Ketimpangan Pembangunan Antar Daerah di Provinsi Jambi
}

\author{
Rosmeli \\ Dosen Fakultas Ekonomi Program Studi Ekonomi Pembangunan Universitas Jambi \\ Email:rosmeli.vina@yahoo.com
}

\begin{abstract}
ABSTRAK
Pembangunan Infrastruktur merupakan salah satu aspek penting dan vital untuk mempercepat proses pembangunan nasional dan regional. Infrastruktur juga mempunyai peranan penting sebagai salah satu roda penggerak pertumbuhan ekonomi. Laju pertumbuhan ekonomi dan investasi suatu Negara maupun daerah tidak dapat dipisahkan dari ketersediaan infrastruktur seperti transportasi, telekomunikasi, sanitasi, dan energy. Inilah yang menyebabkan pembangunan infrastruktur menjadi pondasi dari pembangunan ekonomi yang berkelanjutan. Bertambahnya infrastruktur dan perbaikannya oleh pemerintah diharapkan memacu pertumbuhan ekonomi dan mengurangi ketimpangan pembangunan.
\end{abstract}

\section{Kata Kunci: Jalan dan Listrik}

\section{PENDAHULUAN}

\section{Latar Belakang}

Tidak ada yang memungkiri betapa pentingnya peran infrastruktur dalam aktivitas ekonomi. Dalam laporan Bank Dunia tersebut ditunjukkan beberapa studi yang secara jelas memaparkan kaitan di antara keduanya. Di pedesaan India, misalnya, pembangunan jalan telah meningkatkan pertumbuhan dan produktivitas pertanian (Fan, Hazell, dan Thorat, 1999). Demikian pula, pembangunan jalan di China dan Thailand memberikan kontribusi yang signifikan terhadap pertumbuhan output, baik dalam kegiatan pertanian maupun nonpertanian (Fan, 2000, 2002, 2004). Hal yang sama juga terjadi di Meksiko, di mana pembangunan jalan memberikan donasi yang kuat terhadap peningkatan produktivitas tenaga kerja (Deichman, 2002). Oleh karena itu, semua negara berkembang selama satu dekae terakhir berlomba-lomba memerbaiki infrastruktur untuk mendongkrak pembangunan ekonominya (Barus 2012).

Pembangunan Infrastruktur merupakan salah satu aspek penting dan vital untuk mempercepat proses pembangunan nasional dan regional. Infrastruktur juga mempunyai peranan penting sebagai salah satu roda penggerak pertumbuhan ekonomi. Laju pertumbuhan ekonomi dan investasi suatu Negara maupun daerah tidak dapat dipisahkan dari ketersediaan infrastruktur seperti transportasi, telekomunikasi, sanitasi, dan energy. Inilah yang menyebabkan pembangunan infrastruktur menjadi pondasi dari pembangunan ekonomi yang berkelanjutan. Bertambahnya infrastruktur dan perbaikannya oleh pemerintah diharapkan memacu pertumbuhan ekonomi (Suratno dalam Sumadiasa, 2016)

Infrastruktur jalan merupakan sektor yang sangat penting dalam perkembangan dan pengembangan wilayah yang cukup substansial sehingga kontribusi investasi sektor infrastruktur jalan terhadap pertumbuhan dapat dikatakan signifikan. Peningkatan kegiatan 
ekonomi dan sosial di daerah yang telah berkembang, sedang berkembang ataupun akan berkembang, dapat meningkatkan pergerakan manusia dan barang dari dan ke pusat-pusat pelayanan,produksi, pusat kota, pusat-pusat permukiman atau konsumsi sehingga membutuhkan prasarana jalan dengan kualitas tinggi serta tingkat aksesibilitas dan mobilitas yang memadai.

Sama halnya dengan infrastruktur jalan, infrastruktur listrik merupakan energy yang penting, listrik digunakan untuk bermacam - macam aktivitas dalam kehidupan sehari - hari. Tanpa adanya listrik maka aktivitas akan menjadi terhambat baik dalam ekonomi maupun dalam sosial.

Sebagai salah satu bagian dari wiayah Indonesia, Provinsi Jambi terus berupaya untuk meningkatkan infrastruktur Jalan dan Listrik yang ada. Dari 1.129,91 Km total panjang jalan Provinsi Jambi, 73,3\% tergolong kondisi mantap pada tahun 2015. Untuk infrastruktur listrik pada tahun 2015 sebesar 328 MW dengan jumlah pelanggan sebanyak 653.016 dan pada tahun 2016 mencapai mengalami peningkatan menjadi 365 MW dengan jumlah pelanggan sebanyak 703.769.

Dengan kondisi jalan yang baik dan jumlah listrik yang tersambung semakin banyak, maka diharapkan pertumbuhan ekonomi antar daerah di Provinsi Jambi menjadi semakin baik yang akan berdampak pada peningkatan pendapatan masyarakat dan mengurangi ketimpangan pembangunan. Bila dilihat dari kontribusi terhadap perekonomian, daerah produksi memberikan kontribusi yang cukup besar dalam aktivitas perekonomian daerah, karena hasil - hasil produksi pertanian dan perkebunan menyebar di desa - desa yang ada di provinsi Jambi begitu pula hasil - hasil UMKM yang masih belum tersentuh oleh teknologi karena salah satu faktor yang tidak mendukung yaitu infrastruktur listrik. Hal ini akan berdampak pada tingkat kesejahteraan masyarakat yang rendah dan kurangnya pemerataan hasil - hasil pembangunan yang akan menyebabkan ketimpangan pembangunan menjadi tinggi. Berdasarkan uraian diatas, yang menjadi permasalahan dalam penelitian ini adalah:

1. Bagaimana ketimpangan pembangunan di Provinsi Jambi?

2. Bagaimana dampak infrastruktur jalan dan listrik terhadap ketimpangan pembangunan di Provinsi Jambi?

\section{METODE PENELITIAN}

Dalam penelitian ini data yang digunakan adalah time series data yang berbentuk time series dalam periode 2001-2016 yang diperoleh dari lembaga atau instansi resmi pemerintah dan dari situs-situs internet yang telah diolah lebih lanjut.

Pengumpulan data pada penelitian ini menggunakan metode perpustakaan (Library Research) yaitu melakukan studi kepustakaan dengan mempelajari buku-buku, literature, jurnal-jurnal penelitian, artikel, situs-situs internet, serta sumber lainnya yang berkaitan dengan objek penelitian.

Metode analisis yang dipergunakan dalam penelitian ini adalah penelitian deskriptif yaitu penelitian yang dimaksudkan untuk menyampaikan informasi mengenai gejala-gejala yang ada pada saat penelitian Metode analisis data yang digunakan dalam penelitian ini adalah: 


\section{Analisis Kuantitatif}

Untuk menjawab tujuan pertama, maka digunakan Willliamson Indeks,yaitu:

$$
\mathrm{WI}=\frac{\sqrt{\sum(Y i-Y)^{2} \cdot F_{i} / n}}{Y}
$$

Dimana :

$\mathrm{Wi}=$ Nilai / indeks ketimpangan wilayah / provinsi

Yi $=$ Pendapatan perkapita masing-masing provinsi

$\mathrm{Y}=$ Total pendapatan perkapita kawasan indonesia

$\mathrm{Fi}=$ Jumlah penduduk masing-masing provinsi

$\mathrm{N}=$ Jumlah penduduk Indonesia.

Besarnya $\mathrm{Vw}$ adalah $0 \leq \mathrm{Vw} \leq 1$

$\mathrm{Vw}=0$, berarti pembangunan wilayah sangat merata

$\mathrm{Vw}=1$, berarti pembangunan wilayah sangat tidak merata (kesenjangan sempurna)

$\mathrm{Vw} \sim 0$, berarti pembangunan wilayah semakin mendekati merata

$\mathrm{Vw} \sim 1$, berarti pembangunan wilayah semakin mendekati tidak merata.

Untuk menjawab tujuan kedua maka di gunakan regresi berganda semi log dengan Persamaan regresi berganda yang digunakan adalah sebagai berikut :

$$
Y=\alpha+\beta_{1} \log X_{1}+\beta_{2} \log X_{2}+e
$$

Keterangan :

$$
\begin{array}{ll}
\mathrm{Y} & : \text { Ketimpangan pembangunan } \\
\alpha & : \text { Konstanta } \\
\beta_{1} \beta_{2} & : \text { Koefisien regresi } \\
\mathrm{X}_{1} & : \text { Panjang Jalan } \\
\mathrm{X}_{2} & : \text { Kwh listrik yang terpasang } \\
\mathrm{e} & : \text { Error Term }
\end{array}
$$

\section{HASIL DAN PEMBAHASAN}

\section{Ketimpangan Pembangunan di Provinsi Jambi}

Ketimpangan pembangunan akan memberikan gambaran seberapa besar ketimpangan pembangunan yang ada di Provinsi Jambi yang diukur dengan indeks Williamson. Berdasarkan hasil perhitungan indeks Williamson rata - rata ketimpangan pembangunan di Provinsi Jambi sebesar 0.383 yang berarti indeks ketimpangan di Provinsi Jambi dalam kondisi sedang. 


\begin{tabular}{cc}
\hline Tabel 1. Indeks Ketimpangan Pembangunan di Provinsi Jambi \\
\hline Tahun & Indeks Williamson \\
\hline 2001 & 0.356 \\
2002 & 0.377 \\
2003 & 0.378 \\
2004 & 0.372 \\
2005 & 0.375 \\
2006 & 0.380 \\
2007 & 0.374 \\
2008 & 0.370 \\
2009 & 0.369 \\
2010 & 0.400 \\
2011 & 0.395 \\
2012 & 0.403 \\
2013 & 0.400 \\
2014 & 0.398 \\
2015 & 0.391 \\
2016 & 0.386 \\
Rata-rata & $\mathbf{0 . 3 8 3}$ \\
\hline
\end{tabular}

Sumber : Data diolah

Dari tabel 1 terlihat bahwa nilai Indeks Williamson (Vw) Provinsi Jambi secara rata-rata selama tahun 2001-2016 sebesar 0,3964, ini berarti ketimpangan pendapatan antar daerah di Provinsi Jambi selama tahun tersebut termasuk kedalam ketimpangan yang tergolong sedang. Sedangkan nilai Vw terendah Provinsi Jambi terjadi pada tahun 2001 juga tergolong sedang sebesar 0,3568. Dan nilai Vw tertinggi pada tahun 2012 sebesar 0,403 tergolong pada ketimpangan pendapatan yang tinggi.

Tingginya ketimpangan pada tahun 2012 dikarenakan adanya apeningkatan aktivitas ekonomi yang cukup besar dibeberapa daerah seperti Kota Jambi, Sarolangun, Bungo dan Tanjaung Jabung Barat yang akhirnya berdampak pada peningkatan pertumbuhan ekonomi daerah tersebut dan peningkatan pendapatan perkapita, sementara daerah - daerah lain memberikan pertumbuhan ekonomi yang tidak jauh mengalami perubahan.

Secara umum, penyebab terjadinya ketimpangan pendapatan antar daerah di Provinsi Jambi ini yaitu faktor kepemilikan sumber daya alam dan faktor persebaran penduduk. Beberapa Kabupaten/Kota seperti Kabupaten Tanjung Jabung Timur, Tanjung Jabung Barat, Muaro Jambi, Batanghari, Sarolangun, dan Tebo memiliki sumber minyak dan gas alam sementara Kabupaten/Kota lainnya tidak memiliki sumber migas. Seperti diketahui produksi migas agak sulit diprediksi begitu juga dengan harganya. Harga migas yang tinggi akan berdampak meningkatnya nilai PDRB pada daerah-daerah yang memiliki potensi sumber migas. Peningkatan PDRB akan diikuti dengan peningkatan pendapatan perkapita pada daerah berpotensi, sedangkan daerah yang tidak memiliki potensi migas pendapatannya cenderung rendah dibanding daerah berpotensi. 


\section{Dampak Infrastruktur Terhadap Ketimpangan Pembangunan}

Infrastruktur memegang peranan penting dalam memperkecil ketimpangan pembangunan antar wilayah, infrastruktur jalan dan infrastruktur listrik merupakan infrastrutkur yang sangat berperan penting dalam meningkatkan ekonomi masyarakat yang pada akhirnya akan memperkecil ketimpangan. Berdasarkan hasil olah data, maka dilakukan uji hipotesis untuk variable - variable yang ada dalam penelitian ini baik secara overall maupun secara parsial.

Berdasarkan hasil uji secara keseluruhan diperoleh nilah $\mathrm{F}$ hitung sebesar 9.776 dengan probabilita sebesar 0.03, ini berarti panjang jalan provinsi dan jumlah kwh (listrik) yang terpasang di Provinsi Jambi secara bersama - sama berpengaruh signifikan terhadap ketimpangan pembangunan. Sedangkan pengaruh variable secara parsial dapat dilihat sebagai berikut:

1. Panjang Jalan mempunyai nilai th sebesar 1.229 dengan probabilita sebesar 0,241 , artinya panjang jalan mempunyai pengaruh yang tidak signifikan terhadap ketimpangan pembangunan di Provinsi Jambi. Panjang Jalan tidak mempunyai pengaruh signifikan dikarenakan, panjang jalan provinsi merupakan total panjang jalan tanpa melihat kondisi darinjalan tersebut, jalan mempunyai pengaruh terhadap penurunan ketimpangan pembangunan adalah jalan dalam kondisi baik dan sedang, sedangkan jalan dalam kondisi rusak ringan dan rusak berat akan memperbesar ketimpangan pembangunan antar wilayah.

2. Listrik mempunyai nilai th sebesar 4.390 dengan probabilita sebesar 0.001 , ini berarti listrik yang terpasang mempunyai pengaruh yang signifikan terhadap ketimpangan pembangunan. Ini tidaklah mengherankan karena listrik yang terpasang dapat meningkatkan ekonomi masyarakt, sehingga dapat meningkatkan pendapatan masyarakat yang pada akhirnya dapat mengurangi ketimpangan pembangunan antar wilayah. Dari 5 variabel yang mempengaruhi produksi karet, 2 variabel yaitu luas tanamah dan jumlah tanaman mempunyai pengaruh signifikan terhadap produksi karet, sedangkan umur tanaman, jumlah tenaga kerja dan biaya pemupukan mempunyai pengaruh yang tidak signifikan terhadap produksi karet.

Berdasarkan hasil olah data dapat diketahui persamaan sebagai berikut:

$\mathrm{Y}=\beta_{0}+\beta_{1} \log \mathrm{X}_{1}+\beta_{2} \log \mathrm{X}_{2}+\mathrm{ei}$

$=-0.426+0.019 \log \mathrm{X}_{1}+0.084 \log \mathrm{X}_{2}+\mathrm{ei}$

Dari hasil olah data diperoleh nilai:

1. Konstanta sebesar -0.426 , ini berarti jika panjang jalan provinsi dan listrik yang terpasang di Provinsi tetap maka ketimpangan pembangunan natar daerah akan mengalami penurunan sebesar 0.426 indek.

2. Nilai koefisien regresi $\beta_{1}$ sebesar 0.019 ini berarti jika pertambahan panjang jalan provinsi sebesar 1 persen maka ketimpangan pembangunan di Provinsi Jambi akan meningkatkan sebesar 0.019 indek dengan asumsi factor lain dianggap tetap.

3. Nilai koefisien regresi $\beta_{2}$ sebesar 0.084 , ini berarti jika penambahan 1 persen kwh listrik yang terpasang di Provinsi Jambi akan meningkatkan ketimpangan sebesar 0.084 indek dengan asumsi factor lain dianggap tetap 
Nilai koefiesien determinasi regresi sebesar 0,775 ini berarti 77.5 persen ketimpangan pembangunan di Provinsi Jambi dipengaruhi oleh panjang jalan Provinsi dan kwh listrik yang terpasang sedangkan sisanya 22.5 persen dipengaruhi oleh factor - factor lain diluar penelitian ini.

\section{DAFTAR PUSTAKA}

Ahmad Yustika, 2011. Korupsi Infrastruktur dan Ketimpangan Pembangunan, diakses 5 Maret 2017.

Barus, Yosep 2012. Dampak pembangunan infrastruktur jalan terhadap perekonomian dan distribusi pendapatan intra dan interregional kawasan barat dan timur Indonesia: suatu analisis model interregional social accounting matrix. http://repository.ipb.ac.id/handle/123456789/55082, diakses 5 Maret 2017

Delis, Arman, 2008. Peran Infrastruktur sebagai pendorong dinamika ekonomi sektoral dan regional berbasis pertanian. Disertasi Sekolah Pascasarjana Institut Pertanian Bogor.

Kuncoro, Mudrajad. 2004, Otonomi dan Pembangunan Daerah, Jakarta: Erlangga.

Kuncoro, Mudrajat.2006. Ekonomika Pembangunan (Teori, Masalah, dan Kebijakan), Yogyakarta: UPP-STIM YKPN d/h YKP.

Landiyanto, Erlangga Agustino (2005). Kinerja Keuangan dan Strategi pembangunan Kota di Era Otonomi Daerah: Studi Kasus Kota Surabaya. Cures Working Paper, No. 05/01.

Mangkusubroto, Guritno. 1995. Ekonomi Publik, Edisi Ketiga, Yogyakarta: Lembaga penerbit FE UGM.

Mccann, P, 2001. "Urban and Regional Economic". Oxford University Press, New York.

Mopangga Helwin, 2011. Analisis Ketimpangan Pembangunan dan Pertumbuhan Ekonomi di Provinsi Gorontalo Trikonomika Volume 10, No. 1, Juni 2011, Hal. 40-51 ISSN 1411$514 \mathrm{X}$

Sjafrizal, 2008. Ekonomi Regional Teori dan Aplikasi. Sumatera Barat: Baduose Media.

Sumadiasa dkk, 2016. Analisis Pengaruh Infrastruktur Jalan, Listrik dan PMA terhadap pertumbuhan PDRB Provinsi Bali Tahun 1993 - 20014. E-Jurnal Ekonomi Pembangunan No.5 Vol 7 Juli 2016 Universitas Udayana, Diakses tanggal 8 maret 2017 Triyaningsih dan Rosmeli pada "Disparitas Pendapatan di Provinsi Jambi" Periode 20002008, Majalah Perspektif Bapedda 2010.

Tarigan, Robinson. 2005. Ekonomi Regional Teori dan Aplikasi. Edisi Revisi. Jakarta: PT Bumi Aksara.

Todaro, M.P. 2000. Pembangunan Ekonomi Dunia Ke Tiga. Edisi Ketujuh. Ja karta: Erlangga. Todaro, MP \& Stephen C. Smith. 2004. Pembangunan Ekonomi Dunia Ke Tiga. Edisi kedelapan. Jakarta: Erlangga. 